\title{
Drip Irrigation Design and Management
}

\author{
O.P. Suryawanshi* \\ B.R.S.M. College of Agricultural Engineering and Technology, Mungeli, Indira Gandhi Krishi \\ Vishwavidyalaya, Raipur, C.G., India \\ *Corresponding author
}

\section{A B S T R A C T}

Irrigation is one of the artificial way of supplying water to the plants/crops. The amount of water which will be available at the root zone of the plants depends upon the method of irrigation. The efficient use of water greatly

Keywords

Irrigation, Drip,

Water,

Efficient use,

Evaporation

Article Info

Accepted:

07 March 2018

Available Online:

10 April 2018 depends on that where and how water is applying. Efficient use of is necessary to conserve the water for future use. Since water resources are exhaustible so it needs to conserve. Moreover, the use of water in proper way during irrigation enhances the productivity at same investment. Drip irrigation is efficient method of irrigation because, water drops are direct delivering at the plants root zone. In this method, water drops are moves under pressure inside of main, sub main, lateral and delivers through dripper. Drip irrigation is a type of micro irrigation, where laterals and drippers may install on the surface or buried bellow the soil surface. The main aim of drip irrigation is to deliver the water particles directly at the root in order to minimize the evaporation loss. The efficiency of drip irrigation depends mainly on the design, maintenance and operating condition. I this study the basic theory, design part and experimental parameters are described well.

\section{Introduction}

Drip irrigation is the methods of applying uniform and precise amount of water directly to the root zone of the plants as per the requirement, through emitter at frequently interval over a long period of time, via a lowpressure pipe network comprising of mains, submain and laterals. In this system water is applied drop by drop or by micro jet, on the soil surface or below it (subsurface), at a rate lower than the infiltration of the soil.

\section{Principal}

Drip Irrigation is the most scientific method of irrigation which has the following features: Water is applied at a low rate to maintain optimum air-water balance within the root zone. 
Water is applied over a long period of time drop by drop.

Water is applied daily at frequent interval as per the water requirement of plants.

Water is applied via a low pressure piping system.

Water is supplied to the plants and not to the entire field.

The soil moisture content is always maintained at Field Capacity "of the soil and hence the crops grow at a faster rate consistently and uniformly.

\section{Advantages}

\section{Water saving}

About 30 to $70 \%$ of water is saved as losses due to seepage in transmission deep percolation and evaporation are minimized. More than double land area irrigated using the water thus saved.

\section{Increase in yield}

The system facilitated water application at regular interval thereby maintaining optimum moisture level in the root zone for a longer period and prevents moisture stress or shock associated with other methods of irrigation. This promotes optimum plant performance resulting in higher yield and better quality produce.

\section{Improved quality of producer and early maturity}

Crop quality improvement and early maturity is a result of healthy uniform growth of plant. In addition to this, damages and losses due to water contact with fruit or foliage are eliminated.

\section{Control weed growth}

Water is applied directly in the root zone, wetting only a fraction of the soil eliminating weed growth.

\section{Saving in fertilizers and labour costs}

There is consideration saving in labour costs due to reduces inter-culturing operation, lesser number of weeding and elimination of manual operation of fertilizer. About $30-40 \%$ saving in cost of fertilizer is also effected as the fertilizers are applied through the drip irrigation system directly in the root zone of the plants.

\section{Improved disease control}

Disease control is enhanced under micro irrigation system, because the soil moisture and chemical additive levels can be closely controlled.

\section{Ideally suited for difficulty terrain and problematic soil and water}

Using drip irrigation vast area of waste lands such as undulating terrain, saline, waterlogged, sandy and hilly land can be brought under productive cultivation.

It also eliminated the need of land leveling and removal of productive top soil. Drip irrigation can be used on saline soil even with brackish water. As a matter of fact, for undulating hilly waste-land there is no substitute of micro irrigation. The pressure compensating mechanism ensures equal discharge of water to the plant even if the plants are at different levels of the sloping land.

\section{Saving in energy for pumping}

The reduction in electric power consumption due to low pressure requirement and reduction 
in volume of water to be pumped facilitate about $30-50 \%$ saving in the cost of pumping.

\section{Operating suitability}

As the system is unaffected by environmental changes, it can be operated in any season, during night hours and during high winds also.

\section{Components of drip irrigation system}

Drip system is tailor system. The system is designed to suit the system components are so selected that they fulfill the functional requirement and are installed as per the design. The components of the system are as follows:-

Pump

Header assembly

Filters- Hydro-cyclone, sand, screen filter.

Fertigation equipment- Ventury Injector, Fertilizer tank, Injector pump.

Main line.

Submain line.

Valves.

Laterals/polytubes or Inline.

Emitters- drippers, Mini Sprinklers, Jets.

\section{Pump}

The water from the source has to be supplied under appropriate pressure and discharge.

For good performance of the system, the pump should be selected very carefully to suit the type of water source and its yield. Pump is to be purchased by the farmer at his own cost.

\section{Header assembly}

Header assembly consists of by-pass arrangement, non-return valve and air release valve. To control the flow and pressure of the drip irrigation system, a "by-pass valve arrangement" is a must. The water in excess of the design discharge is diverted back to the well (or the source) by operating the by-pass valve.

\section{Filters}

Proper filter station is the heart of the microirrigation system. Water is not found in its purest form in nature. It always contains physical, chemical and biological impurities. If these impurities are not filtered out at the source, it may lead to clogging of the system. The types of filters (sand filter) screen filter (screen/disc).

The types of filter to be used in the system depend on the quality of water and their capacity depends in the design discharge.

\section{Hydro-cyclone filter}

Hydro-cyclone filter is used to remove solid particles of sizes 75 microns (200 mashes) or above having density higher than water such as fine sand and silt, etc.

\section{Media (sand) filter}

The surface water such as river, pond, lake or canal or exposed to direct sunlight and provides favorable conditions for growth of biological impurities like algae, plankton etc.

Media (sand) filter is used to remove large volume of organic and in-organic contaminates from the source water. The filtering media provides three dimensional filtration to trap algae, trash, tree leaves and other suspended impurities. 


\section{Disc filters}

Disc filter is fitted in series if the media filter in order to remove the solid impurities like fine sand and dust from the irrigation water after it has passed through the media filter. The parts of the disc filter consist of body, one or two filtration elements, gaskets, and cover, inlet, outlet and drainage valves.

\section{Pressure gauge}

Maintaining the normal operating pressure in the system is essential to ensure uniformity of irrigation. Pressure gauge is provided at the filtration unit to indicate this pressure.

Glycerine field pressure gauges are also available. Glycerine acts as a lubricant reduces wear of the internal components of the gauge and protects them from vibration, pulsation, mechanical shocks and corrosion. Glycerine filled pressure gauge have longer service life than the ordinary gauges.

\section{Ventury Injector}

It is a simple, compact and cheapest device available for injecting chemicals and fertilizer through drip irrigation system. It works on the differential pressure across the Ventury tube. Fertilizers are applied at a rate of 60 to 70 liters per hour using Ventury injector.

\section{Fertilizer tank}

The fertilizer, after mixing in water, is filled in the Fertilizer Tank. Due to the pressure difference between the inlet and outlet of the tank, the fertilizer gets mixed in the irrigation water and goes to the plant root zone.

\section{Injector pump}

It is used where precise dose of fertilizer of or other chemical is to be given to the crop in greenhouses. It operated on hydraulic pressure and does not need external electric energy.

\section{Main line}

This is a PVC/Polyethylene pipe line used to carry water from the water source to the Submains. The main line is connected to the filter unit to provide filtered water to the system the length and diameter of the line is decided on-

Distance of well from the main crop.

Dimension of the field (length, width).

Area to be brought under irrigation and the flow rate calculated to meet the crop water requirement and

Slope of the filed.

\section{Submain Line}

Submain also a PVC/Polyethylene pipe lines the supplies water to the laterals. Laterals are connected to the submain on one or both sides of submain using Grommet take-offs. Submain is buried at a depth of 2 to 2.5 feet below to various farm implements used for different cultivation operation in the field.

\section{Laterals}

Laterals are made up of LLDPE material which is quite flexible and strong. It conveys water from submain lines to the root zone via drippers. Laterals are spread in entire field at a spacing that depends on the row to row distance of the crop.

The diameter and the maximum length of lateral depend on the amount of water discharged per hour per meter length of lateral. The ends of laterals are sealed using End Stops, Which can be opened for periodic 
flushing to remove the accumulated salts of other impurities.

\section{Lateral drain valve}

Lateral Drain Valve is used in place of end stop to drain off the dirt from the laterals/ Inlines.It automatically flushes the lateral lines at startling as well as at the end of the irrigation cycle it minimizes the manual efforts for maintenance of laterals and also reduces the chances of clogging of the drippers. The valve seals at pressure of 0.3 $\mathrm{kg} / \mathrm{cm} 2$ and thus acts as an air release valve which releases air at the start up and breaks vacuum at the shut off of the system.

\section{Poly fittings and accessories}

These fittings are used for installing the laterals on submain and inter-connection between laterals. Poly fittings include Multioutlet connector, Tee, Elbow, Adaptor, Take off, End plug or End Stop, etc. which are available in 4-16 $\mathrm{mm}$ size.

\section{Drippers/Emitters}

Dripper is main component of the drip system as it supplies water from laterals to the plant root zone. Type of soil, type of crop, its spacing, age and water requirement are the deciding factors for dripper spacing on the lateral as well as number of drippers to be provided for each plant. Depending upon field topography, drippers of pressure compensating or non-pressure compensating type are used. Four hilly, undulating terrains Pressure compensating types are used. For hilly, undulating terrain pressure Compensating (PC) drippers are used. For flat land or land having very mild slope nonpressure compensating type drippers are used.

Some types of drippers are openable to facilitate cleaning.
Factory sealed drippers are also available which are used where vandalism is the problem or where field operator is not reliable or awareness about the system is very low. To avoid choking of the drippers only filtered water should be used through the drip system is very low. To avoid choking of the drippers only filtered water should be used through the drip system as well as the acid and chlorine treatments should be given regularly as suggested in the water analysis report.

\section{Dripnet Pc}

\section{Pressure regulation (Self compensated)}

Based on pressure differentials between water passage inlets and outlets Regulation range: 5$25 \mathrm{~m}$

Maintains a constant flow rate Large dripper filter area

\section{Ripper flow}

Etc: - 6 MM / DAY

1.2 1/h dripper, $3 X 3$ hours/day.

3, 5 liter/dripper/ irrigation cycle.

3, 5 1/h dripper, 20 hours, twice a week

70 liter / dripper / irrigation cycle.

\section{Uniform wetting in field by drip}

\section{Water requirement of crops}

Before calculating crop water requirements, following points are to be taken into consideration.

Type of crop and its age.

Type of soil.

Evaporation loss from the surface. 
Transpiration loss from leaves.

Canopy area and root zone development.

Plant to plant and row to row spacing.

Wind velocity, humidity etc.

After studying all above factors, the monthwise and age wise water requirement for the crop is decided and accordingly design is made.

As a first step in the proper design of the irrigation System, it is necessary to know the crop water requirement. In general terms, the crop water requirement is equivalent is to the rate of evapotranspiration necessary to sustain optimum plant growth. The accuracy of the determination of crop water requirement will be largely dependent of the type of climatic data available. In order to calculate the water requirement of crops accurately one should know the following.

\section{Crop stage/age of plant}

Water required by a plant varies as per its growth stages. Water requirement is different at the time of sowing when the plant is growing, at flowering stage, at the time of fruiting, ripening, and harvesting.

\section{Saturation capacity of maximum water holding capacity}

In this condition the soil is fully saturated and all the soil pores are filled with water. In this state plant roots get suffocated due to absence of air in the root zone and cannot uptake water properly.

\section{Field capacity}

It is defined as the amount of water held in soil after excess water has drained away and the moisture content has become relatively stable. At field capacity large soil pores are filled with air and the micro pores are filled with water. The soil moisture tension at this stage generally varies from 0.1 to 0.3 atmospheres and roots can uptake water and nutrients with ease. In drip irrigation, the soil moisture content is always maintained at field capacity level.

\section{Permanent wilting point}

It is the soil moisture content at which plants can no longer obtain enough water to meet transpiration needs and remain wilted even if water is added to the soil.

\section{Transpiration}

It is the evaporation of water from plant surfaces directly into the atmosphere or into intercellular spaces and then by diffusion through the stomata to the atmosphere.

\section{Evapotranspiration (ET)}

It is also called as consumptive us. It denotes the quantity of water transpired by plants during their growth of retained in the plant tissues plus the moisture evaporated from the surface of the soil and the vegetation.

\section{Reference crop evapotranspiration (Et0)}

It is defined as the rate of evapotranspiration from an extended surface of 8 to $15 \mathrm{~cm}$ tall green grass cover of uniform height, actively growing, completely shading the ground and not short of water.

\section{Crop factor of crop coefficient (kc)}

The crop factor, kc, is selected for given crop and stage of crop development under prevailing climatic condition. For each crop there are four growth stages. Crop factors have to be determined for each of the stage. The crop factor for the Initial Stage is lower (0.3 to 0.4 ) and it increases to (0.7 to 0.8$)$ during the 
Crop Development Stage. It is about 1.0 to 1.10 at fully Grown Stage and it reduces again to 0.8 to 0.9 at the harvesting stage.

\section{Canopy factor}

The canopy factor indicates the growth of crop at different stages. It is expressed as the ratio of the area covered by plant foliage to the total area provided for the plant.

Thus, it is the ratio of the plants shadow area at 12 noon to the area of the plant. The area provided to a plant is the product of plant spacing and row spacing.

\section{Design of drip irrigation system}

Appropriate design of drip irrigation system is very essential to obtain proper performance and benefits. Each irrigation system should be designed taking into consideration of agro climatic factors, crop physiology, soil characteristics, water source and other engineering factors.

The design of a drip irrigation system consists of the system layout and the determination of the number of laterals to be operated during irrigation. The emitters specifications are decided and laterals, Submains and mainlines are designed. Equipment for filtration and chemical injection is selected as required. Pumping plant specifications are finally worked out.

\section{Design inputs}

As we are aiming at a precise quantity and uniform application of water for each and every plant, collection of data as detailed below is must for designing an efficient drip irrigation system.

Engineering Survey: Measurement of field, ground slope, contours.
Water Source: Assessment of water source and availability of water.

Agricultural Details: Crop, spacing, type, variety, age, water, requirement, crop physiology.

Climatological Data: Temperature, humidity, rainfall, evaporation etc.

Soil and Water Analysis: Collection of soil and water samples and analyzing.

\section{Drip head unit}

\section{Important instructions to farmers before installation}

It is farmer's responsibility to get the trenches dug within the specified time to avoid the delay in installation of your drip irrigation system. The width of trench should be $45 \mathrm{~cm}$ to $70 \mathrm{~cm}$ and the depth of trench should be 75 $\mathrm{cm}$ (2.5 feet) or as I, instructed by our representative. The trenches should be dug in a straight line. The trenches, in which both main and Submains will be laid, should be at least $75 \mathrm{~cm}$ wide. Please ensure that there are no stones or sharp objects in the trenches. If the bottoms of the trenches have hard surface or murum, then put a layer of soft soil at the bottom. Construct a platform of pedestal of brick masonry or cement concrete for filter station as per the dimensions and at the location finalized by our Engineer/Dealer's representative. For Filter station a leveled. Hard surface is required. A platform of brick masonry or cement concrete should be constructed. The size or the platform depends on the size of the sand filter. For 1.5 sand filters, minimum platform size should be $5 \times 3$ feet, whereas for 2"and 3" sand filers, it should be $6 \times 4$ feet and $6 \times 5$ feet respectively for single units. If fertilizer tank is also provided, the platform size will have to be increased accordingly. 
Fig.1 Compact and effective root zone

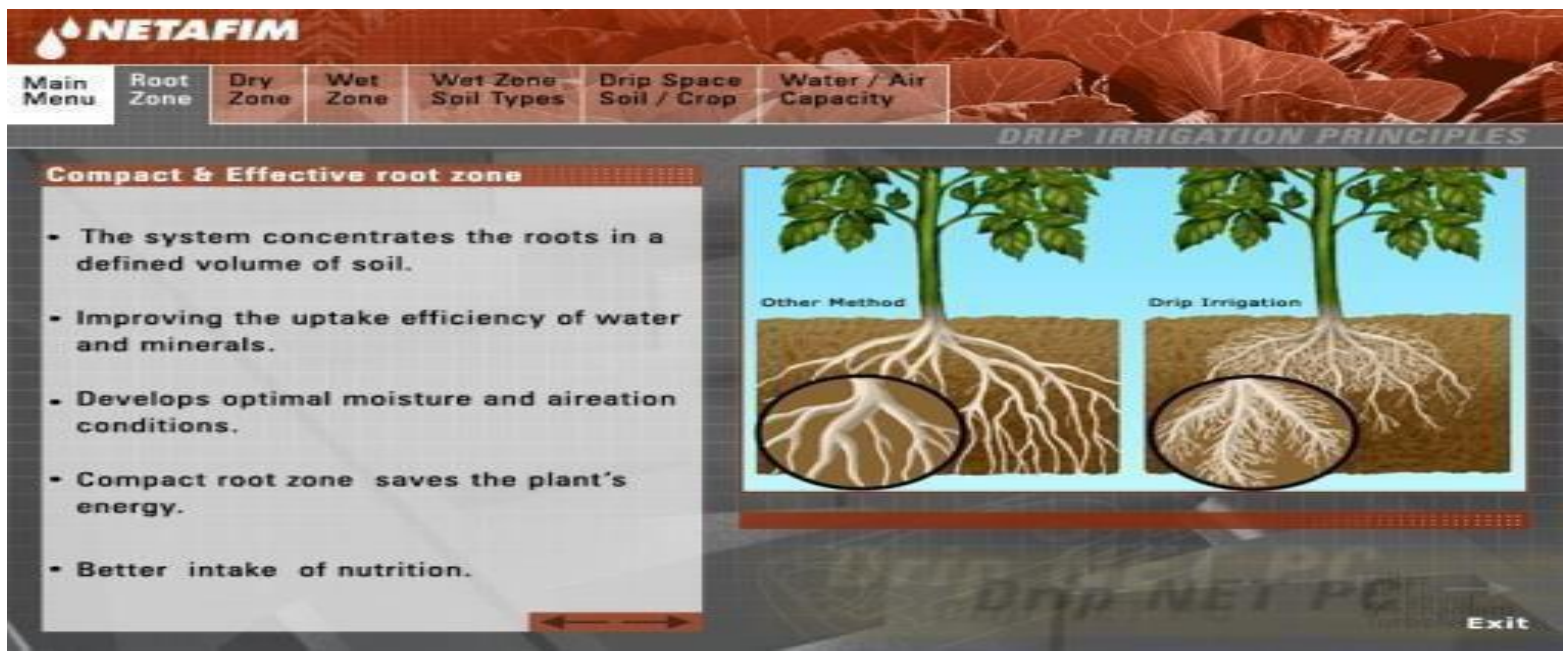

Fig.2a Pump

Fig.2b Header

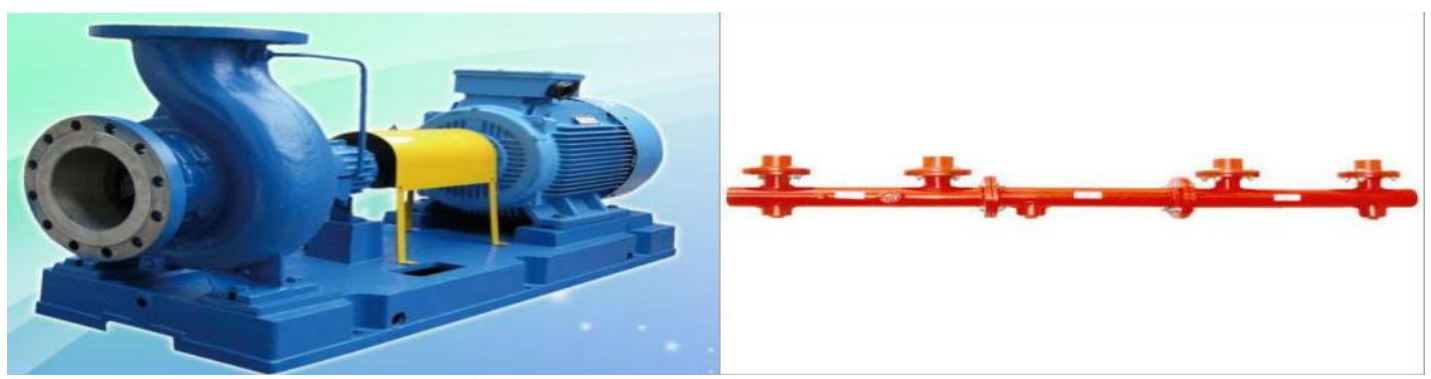

Fig.3 Hydro-cyclone filter

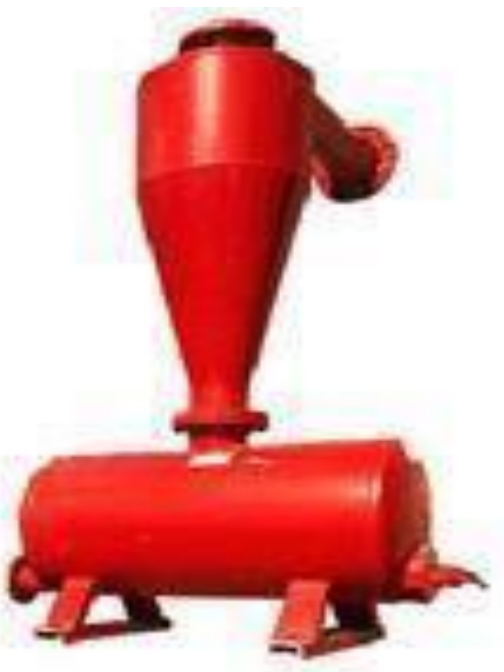


Fig.4 Sand filter

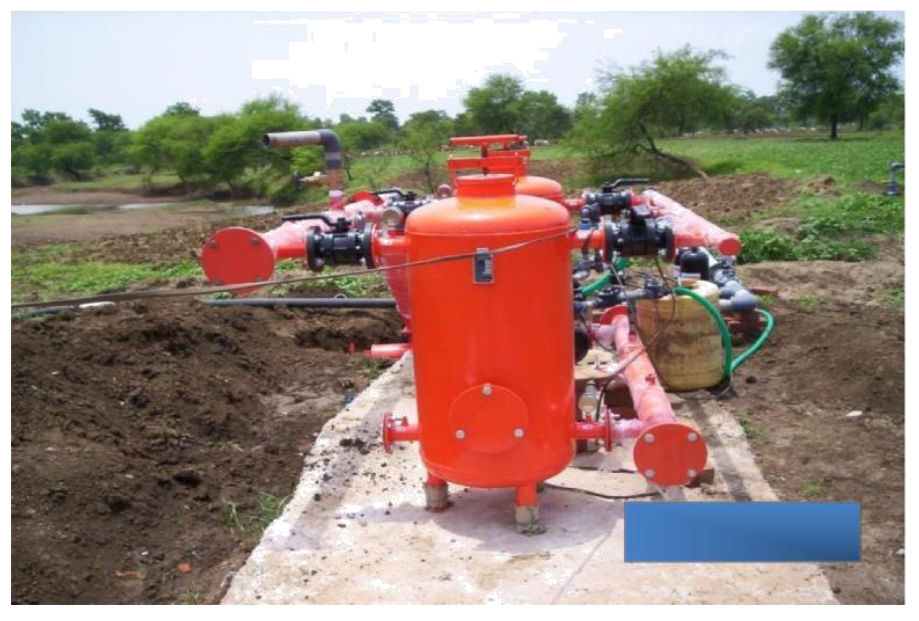

Fig.5 Disc/Screen filters
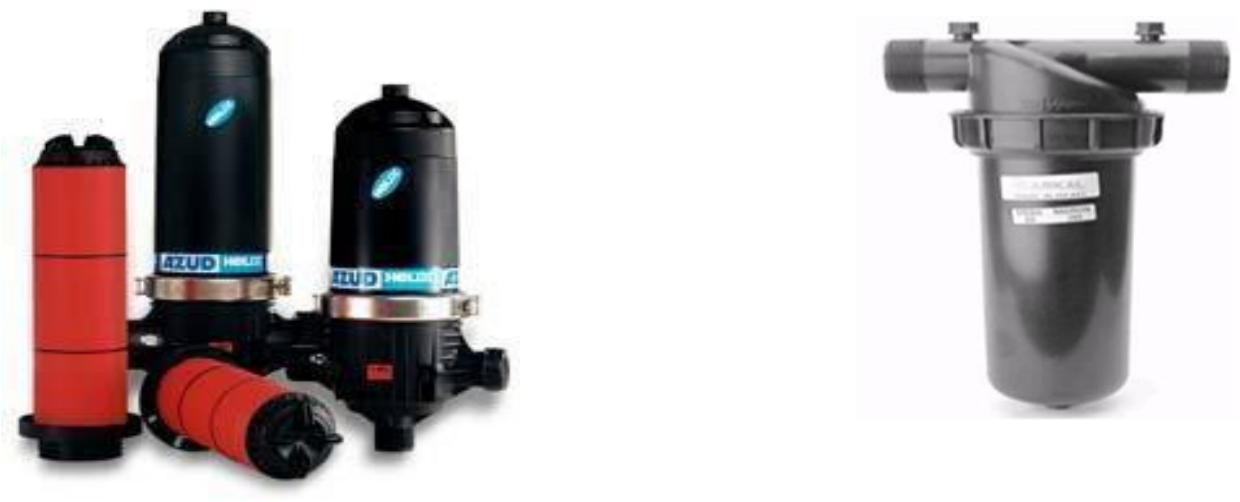

Fig.6 Pressure gauge

Fig.7 Ventury injector

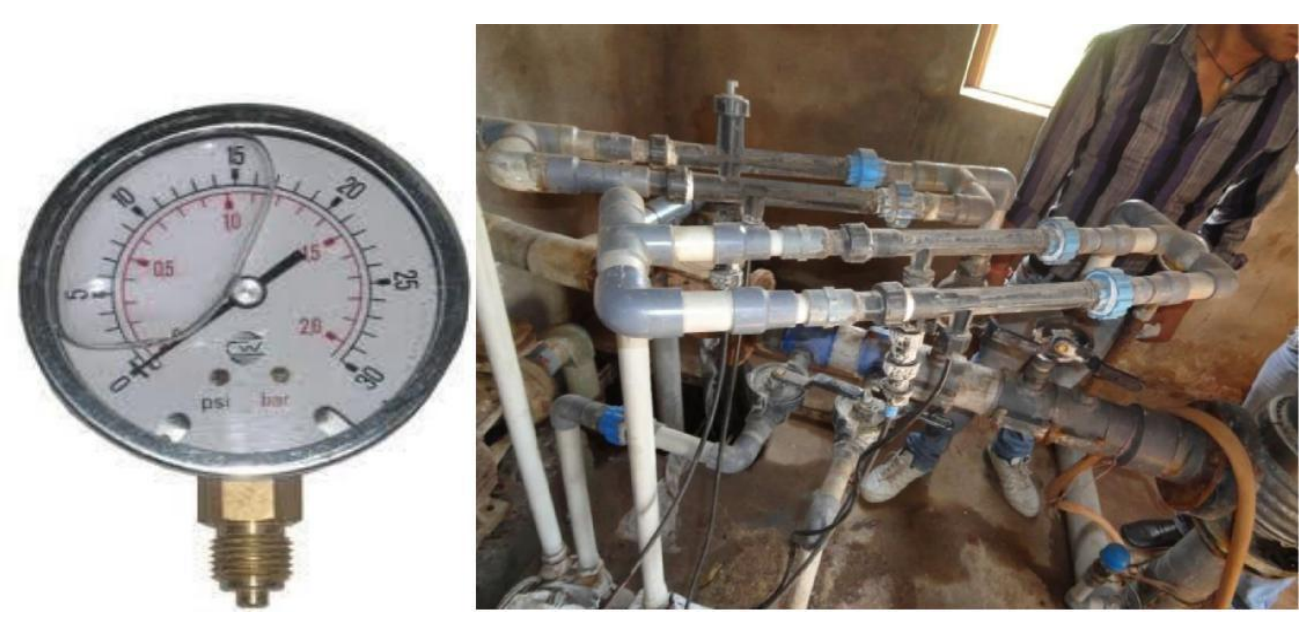


Fig.8 PVC/Polyethylene pipe

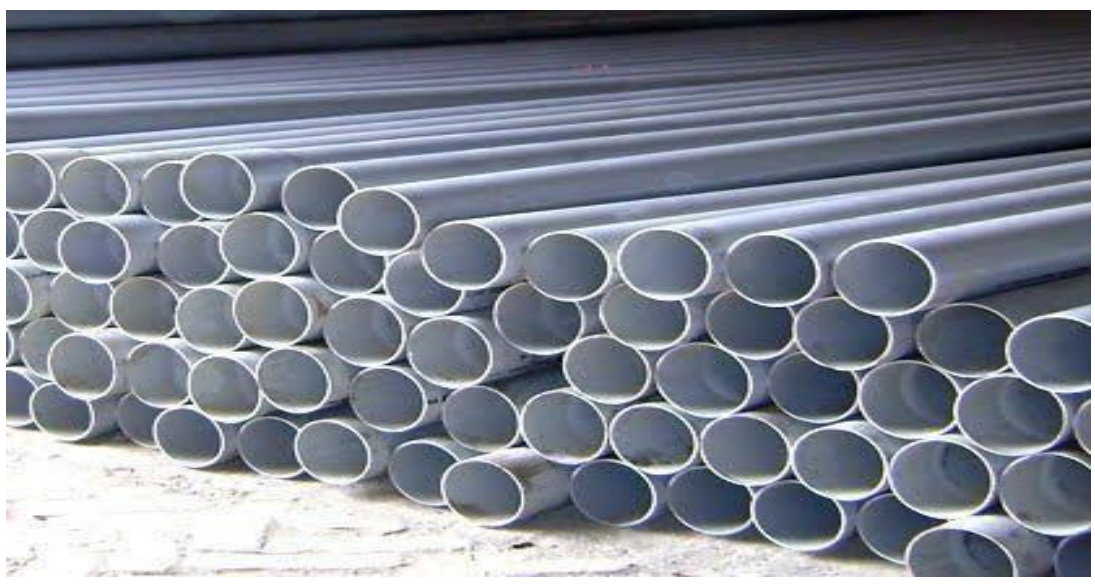

Fig.9 Submain pipe and laterals

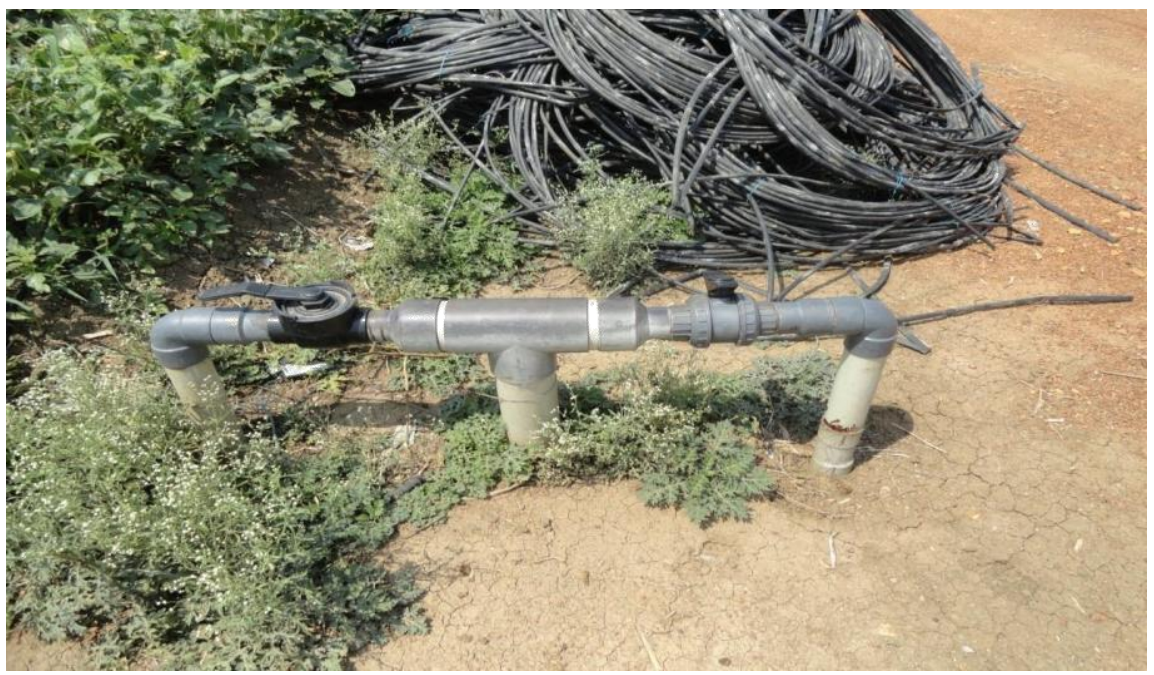

Fig.10 Poly fittings and accessories
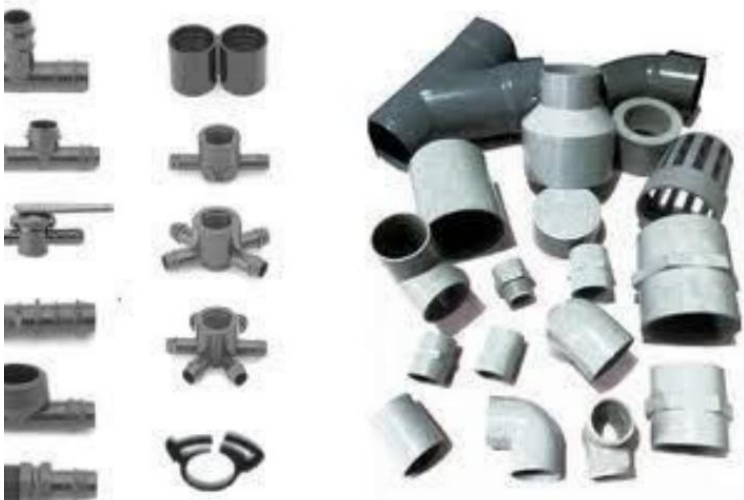
Fig.11 PC or Non PC button drippers
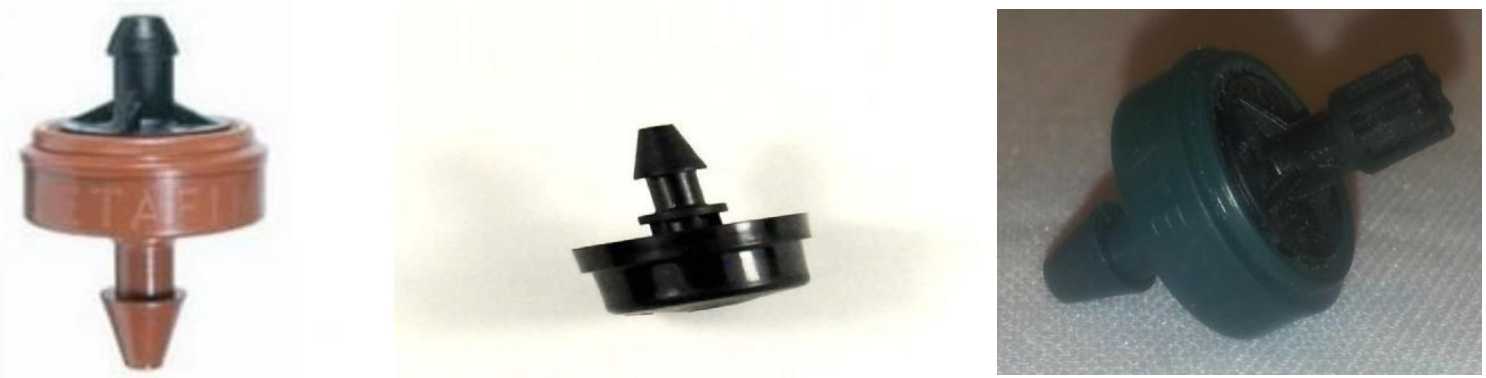

Fig.12 Non- PC dripper
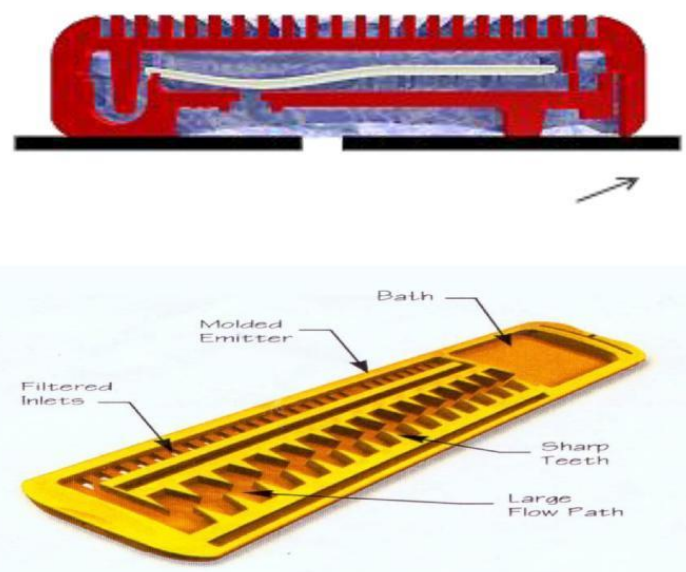

Fig.13 Concept of strip wetting for good yield

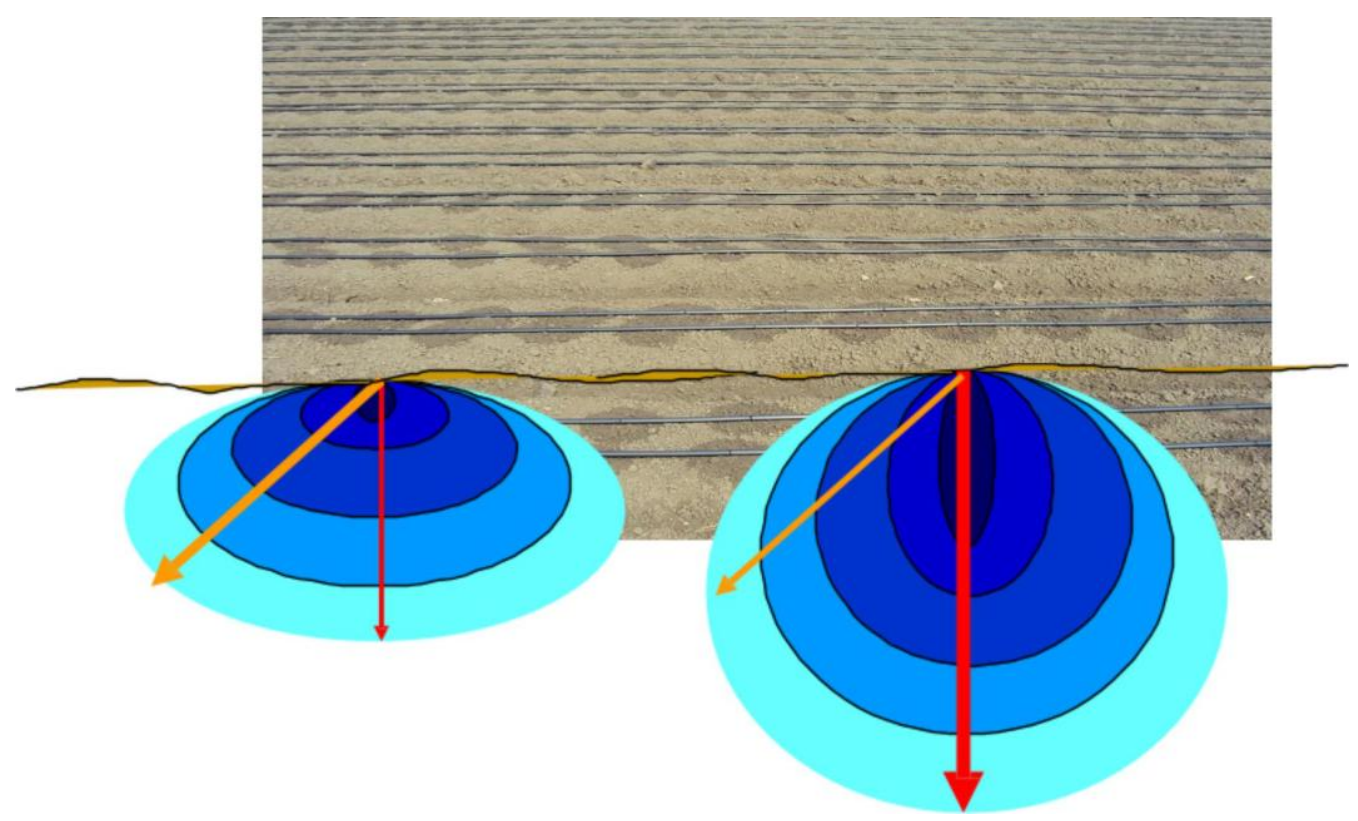


Fig.14 Hydrologic cycle

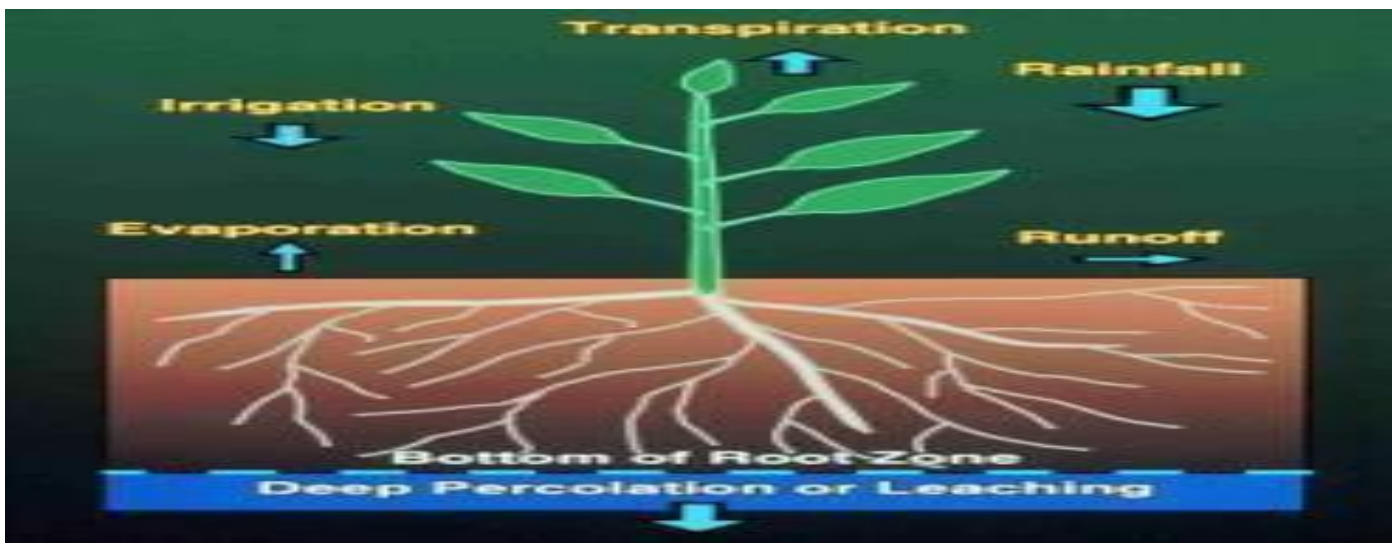

Fig.15 Wetted area for different soils

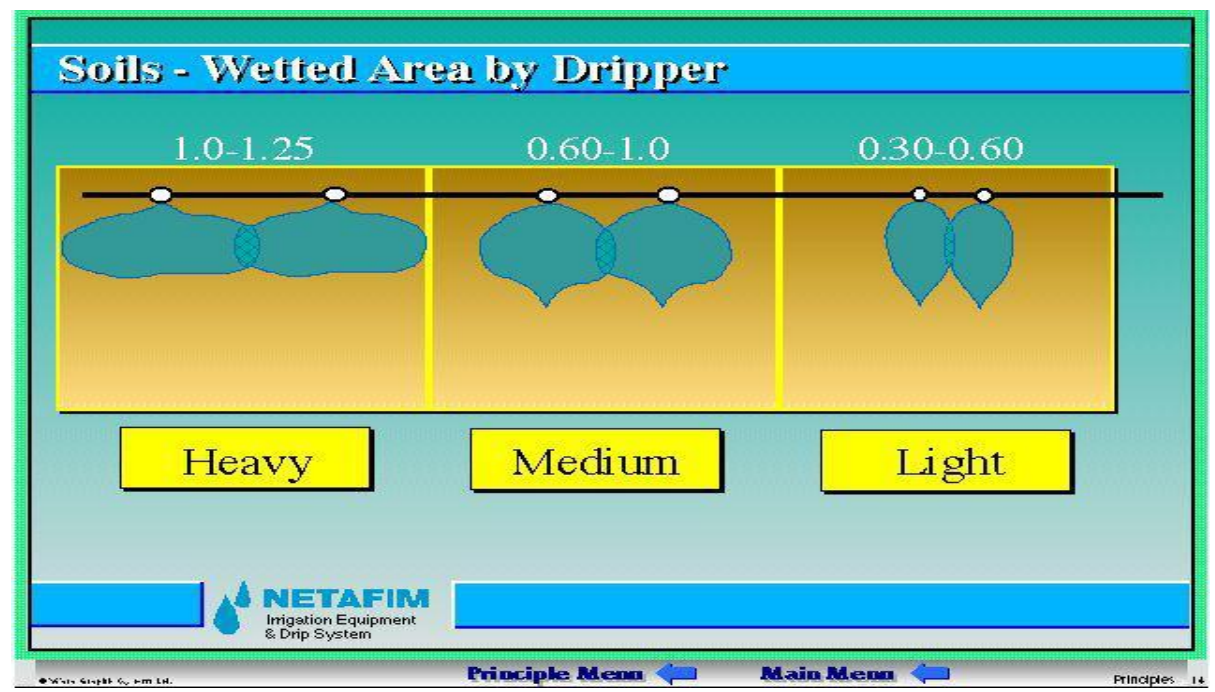

Fig.16 Crop factor of crop coefficient

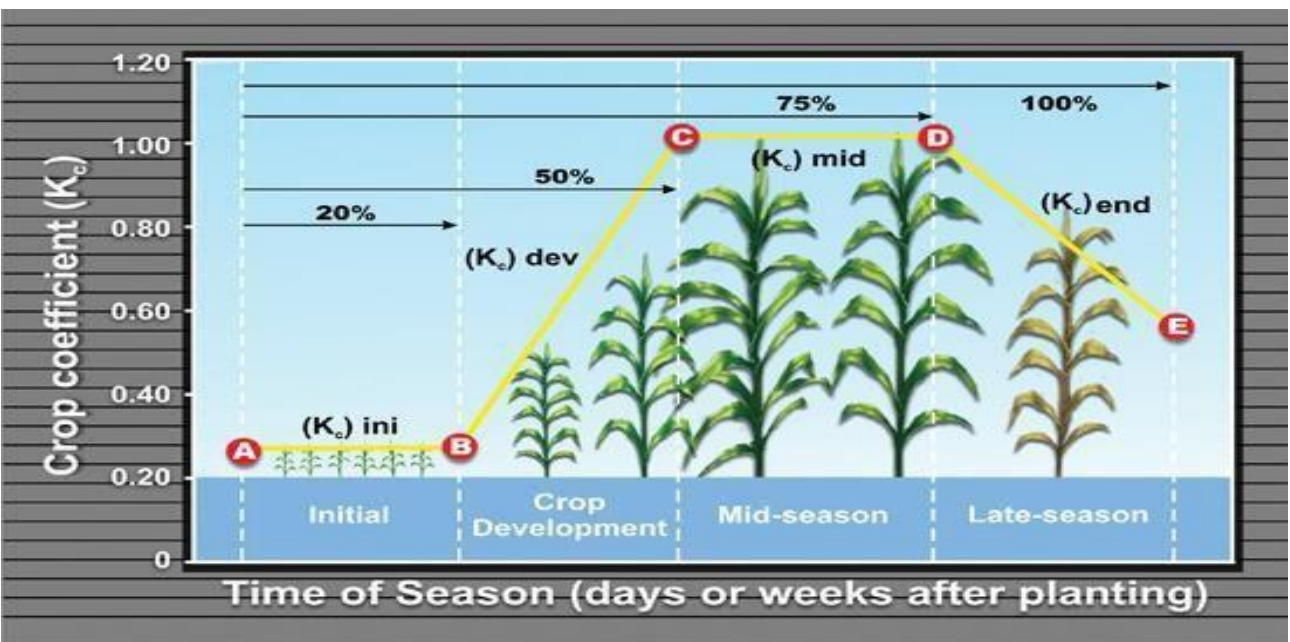




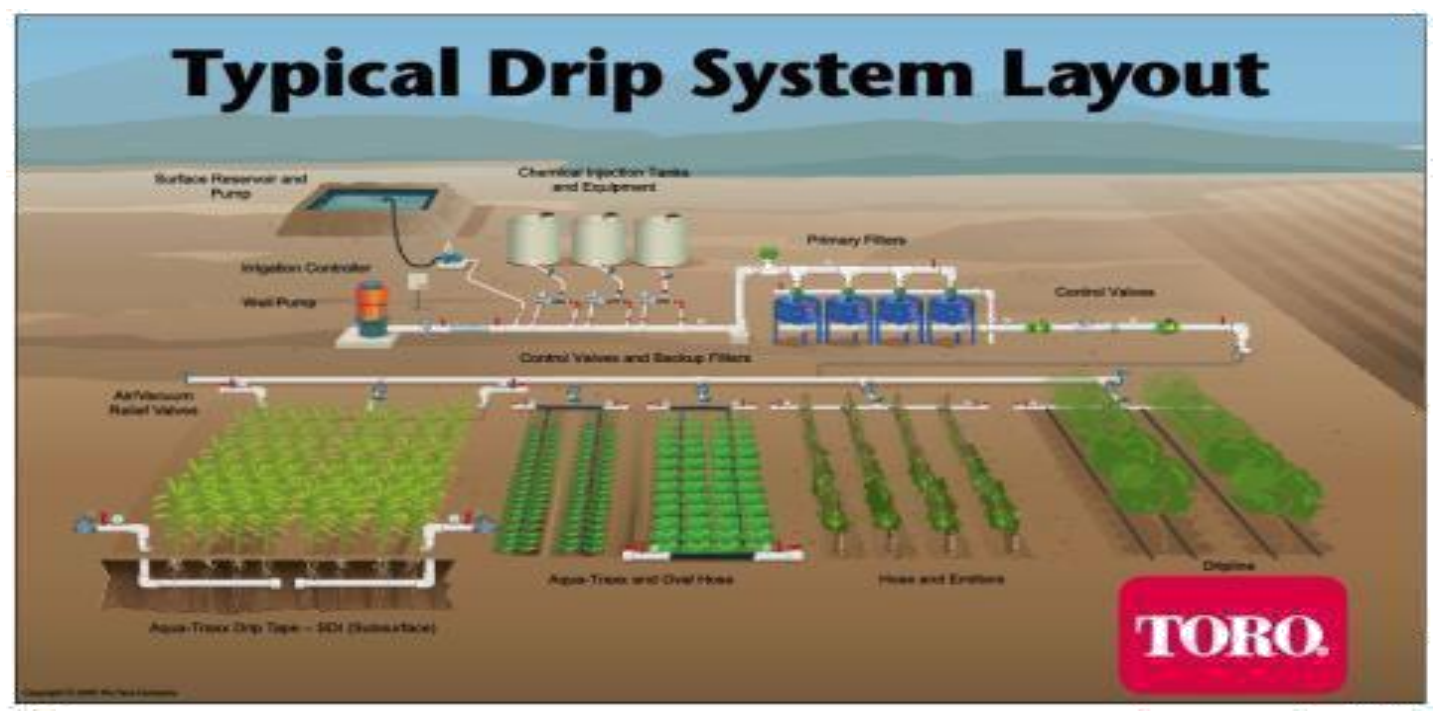

Fig.18 Drip head unit

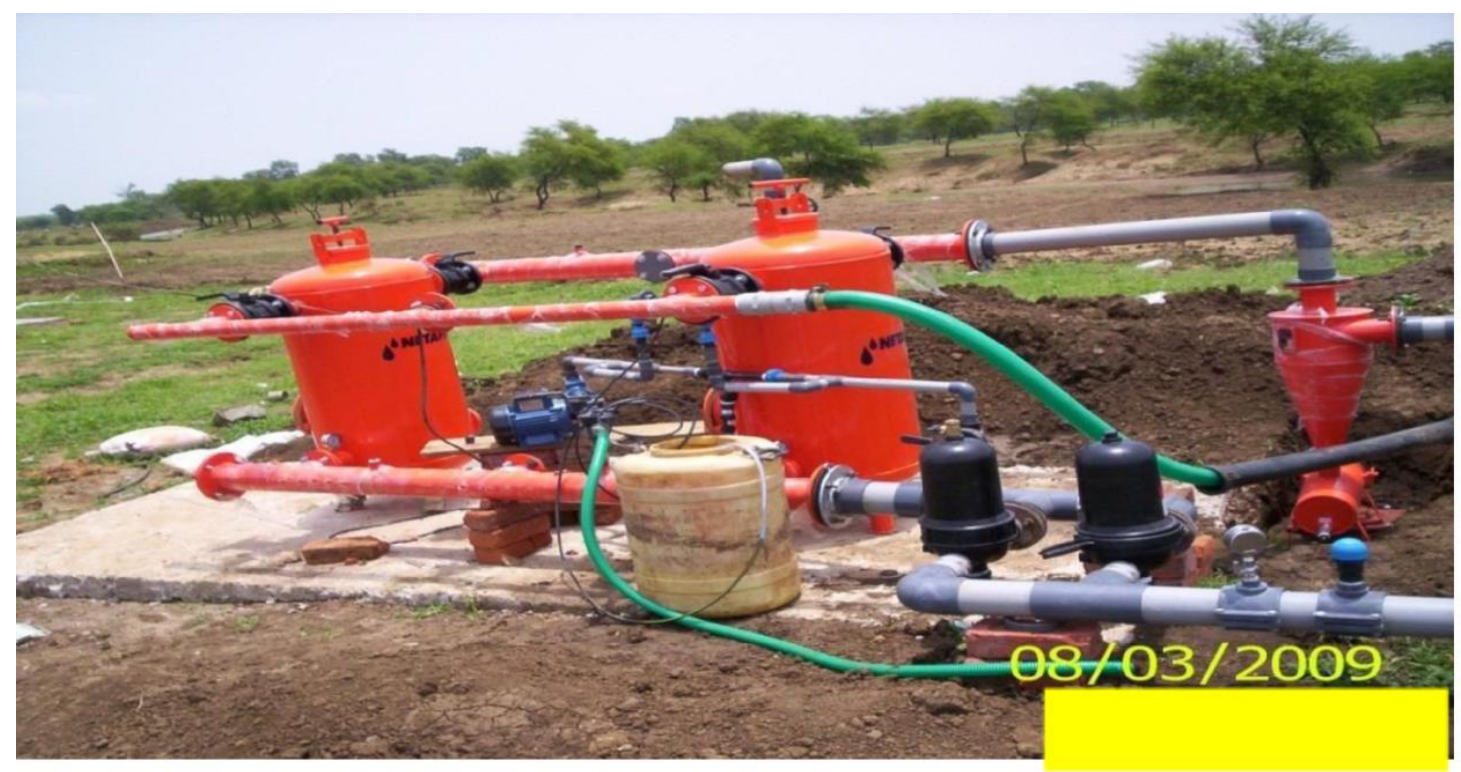

\section{Volume of Water for Tree Crops}

Total volume of water requires $($ liter/day/tree) $=$

Net depth of water

$$
\begin{aligned}
& \% \quad \text { wetted } \\
& \text { covered by foliage }
\end{aligned}
$$

area Spacing b/w Spacing

$x$ trees

$\mathrm{b} / \mathrm{w}$

rows 
While deciding the height of the platform, the height of the hydro cyclone filter (if provided) and its fittings (e.g. pipe bend etc.) should be considered. Inform Company representative (dealer) as soon as the trenches and the platform for filter station are ready.

\section{Installation of drip irrigation system}

\section{Installation of filter station}

Install the sand/screen filters in the correct position on the leveled platform such that adequate space is available for cleaning of filters and for keeping Fertigation equipment.

Ensure that all the fittings such as pressure gauge. Back wash, bypass and air release valves are done properly.

Check that the filter candles and mushrooms are fixed in proper position. Then fill the sand up to the level marked on the filter.

\section{Submain and mainline connections}

Mains and Submains are PVC/HDPE pipe lines PVC pipelines should be laid at depth of minimum 2 feet below the ground surface to avoid possible damage to pipelines due to the form implements used for various cultivation operations in the field.

\section{Design parameters}

Considering the above parameters, an appropriate drip irrigation system has to be designed as per steps given below:

System Capacity.

Selection of Drippers or emitting Devices. Selection and design of Laterals or Tubes. Selection and Design of Submains. Selection and Design of Mainlines. Selection and Design of filtration System. Selection and Design of Pump Unit.

\section{System capacity}

The capacity of the system should be matched with the available quantity of water in the source. In case of a Bore well (Tube Well), system should be designed to match the recharging rate of water. Similarly, in case of Pond, Canal, Reservoir, System should be designed for incoming flow of water to outgoing flow with retention storage capacity.

\section{Selection of drippers or emitting devices}

There are numerous varieties of Drippers / Emitting Tubes available, with different discharge rates, features, functions, characteristics and suitability to different crops. The selection of emitting devices are based on peak water requirements of crop, age and root zone, soil type, topography, soil water holding capacity and infiltration rate, hydraulic conductivity, and cost economy.

\section{Selection and design of laterals or tubes}

Laterals are the conduits which carry water from submain and feed to the emitters and are available in different sizes $12 \mathrm{~mm}, 16 \mathrm{~mm}$ etc. Emitting devices / Drippers can be fitted at determined spacing as per the requirements of crops. In case of inline Drip tubing, dripper intervals and discharge has to be determined before designing of system. As the laterals are significant with regard to pressure variation, proper evaluation of fractional head losses in the laterals is essential to achieve higher uniformity. The size, allowable length and frictional losses of laterals have to be determined by charts and design guidelines provided by the manufacturer for their specific emitting devices.

\section{Selection and design of submains}

Submain is a conduit (PVC / HDPE) which carries water from main line and distributes 
among the laterals. The size, length and frictional head losses of submain have to be determined by charts and design guidelines provided by the manufacturer or by using Hazen - William or Darcy - Weisbach equation and limiting the frictional head losses within the limit of design tolerance of the particular emitting devices as specified by the manufacturer.

\section{Selection and design of mainlines}

Mainlines is a conduit which carries water from source to submain. The size of mainline is determined by considering the quantity of water flowing through it, length and or mainline, elevation of ground, velocity, safety parameters, cost economy and nomograms provided by the manufacturer. While designing the mainline following points should be kept in mind:

Permissible Velocity: Should not exceed 1.5 meter per second.

Frictional Losses: Should be limited to 5 to 50 meter per $1000 \mathrm{~m}$ length of pipe.

Economic size: Should be such that, low initial investment, low annual and low power cost.

Elevation and class of pipe: Minimize use of higher pressure rating (class) of pipes at evated ground. Run the mainline as straight as possible shortest and at the same elevation.

Control measures: Provided air release cum vacuum breaker valves, Non/check valves, pressure relief valves, pressuring and sustaining valves at appropriate locations.

\section{Selection and design of filtration unit}

The selection and design of filtration system is based on:-
Sources of water

Types, size and concentration of physical impurities

Filtration capacity

Type of irrigation system.

Work ability of filtration system

Ease for handling, cleaning, maintenance and repairing

Filtration media and low frication loess

Economical investment, maintenances and power cost

\section{Selection and design of pump unit}

Pump unit is electromechanical device which lifts water from one level to another level with pressure. Pump unit must be capable of supplying required pressure and discharge for efficient functioning of system. Pump system unit can be selected and designed by calculating total head and discharge required for efficient operating of system. Total head required for the system is calculated as:

$($ Suction + Delivery $)+$ Filtration Losses + Frictional Losses in Main Line + Operating Pressure + Fitting Losses + Ventury Head + Elevation (if any)

With Total Head and discharge required,

We can calculate Horse Power required by the pump for efficient operating of drip irrigation system:

H.P. $=\frac{Q \times H}{75 \times a \times b}$

Where - 
Q- Discharge Required in Liter per second.

$\mathrm{H}$ - Total head required in meter.

a- Efficiency of motor (85\%)

b- Efficiency of pump (80\%)

H.P. - Calculated Horse Power.

Note - Refer the manufacturer chart to know the actual Horse Power of Pump.

Some formulae used in design of drip irrigation system

Net Depth of Water: i.e. Evapotranspiration of crop (ETP) Evapotranspiration of crop $(\mathrm{ETP})=\mathrm{Pe} \times \mathrm{Pc} \times \mathrm{Kc}$

Where,

$\mathrm{Pe}=$ Pan evaporation $(\mathrm{mm})$

$\mathrm{Pc}=$ Pan Coefficient, taken as 0.7

$\mathrm{Kc}=$ Crop factor. A crop factor 0.4 to 0.7 should be used for horizontal crops.

\section{Volume of water for row crops}

$\%$ wetted area covered by foliage

Volume of water required/unit area/day $=$ Net depth water $\times \mathrm{Kc}$

\section{Application rate}

Application rate $(\mathrm{mm} / \mathrm{h})=\frac{\text { dripper discharge }(\mathrm{LPH})}{\text { Average Drip line to drip line spacing }(\mathrm{m}) \mathrm{X} \text { dripper spacing (m }}$

\section{Water requirement}

Water requirement $(\mathrm{mm} /$ day $)=P a n$ Evaporation $\times$ crop factor

\section{Irrigation duration}

$$
\begin{aligned}
& \text { Irrigation duration } \\
& \text { Water requirement } / \text { unit area } / \text { day }
\end{aligned}
$$

$$
\text { Application rate/unit area }
$$

\section{Maintenance of drip irrigation systems}

Reliable performance of drip irrigation system depends upon on prevention maintenance that includes proper filtration, pipe flushing, field check of leakage in any component of the system, and monitoring the effective functioning of mechanical device. General maintenance includes periodic checking of drippers, including their discharge, wetting zone, and leakage of pipe and filter gaskets in the lids, flushing valve and fittings. The placement of drippers should be periodically inspected. In case the placement is disturbed they should be put at the proper location. Filter is the hurt of the drip irrigation system. Filter failure will lead to clogging of the entire system. Various methods for cleaning of filters were explained earlier.

\section{Flushing of submain and laterals}

After installation/repairs, the system should be flushed, systematically, beginning with the main line and proceeding to the sub-main, manifolds, and laterals the mainlines and then the submain should be flush one at a time with the many fold or riser valves turned off. Closing the valves on on lines, except the one being flushed, allows a large flow of water. The manifolds should be flushed with all the laterals riser valves turned off. Finally, the laterals hoses should be connected and flushed for about an hour at each operating station

Sometimes silt escapes though the filters and settles in sub-main and laterals father, some algae and bacteria lead to the formation of slimes/pest in the pipe and laterals. To remove these silts and slimes, opening the flush valve should flush the sub-main. Removing the end stock flushes the lateral line by flushing; even the parsecs of accumulated salts will also give remove. Stop the flushing once of water going out is clean. 
Fine sand, silt and clay tend to settle in the low velocity section of the system, at the ends of manifold and laterals emitters resaving high concentration of fine contaminate are susceptible to clogging; therefore, periodic flushing is a recommended part of a good maintenance program. Annual flushing is enough for many systems, but some water and emitter combination require more frequent flushing to control clogging.

\section{Chemical treatment}

Clogging or plugging of drippers will be due to precipitation and accumulation of certain dissolved salt like carbonate, bicarbonate, iron, calcium and manganese salts.

Clogging is also due to the presence of microorganism and the related iron and sulphur slimes due to algae and bacteria. Clogging or plugging is usually avoided/ cleared by chemical treatment of water. Chemical treatment commonly use in drip irrigation systems include addition of chloride and /or acid to the water supply.

\section{Acid treatment}

Sulphuric acid $\left(\mathrm{H}_{2} \mathrm{SO}_{4}\right)$ is injected into drip systems, at the rate suggested. The acid treatment is performed till a $\mathrm{pH}$ of 4 is observed and the system is shut for 24 hours. Next day the system is flushed by opening the flush valve and the lateral ends.

\section{Chlorine treatment}

Chlorine treatment in the form of bleaching powder is performed to inhibit the growth of organisms like algae and bacteria. The blanching powder is dissolve in water and this solution is injected into the system for 30 minutes. Then the system is shutoff for 24 hour. After 24 hour, the lateral ends and flush valves are opened to flush out the water with impurities. Bleaching powder is directly added into the source at a rate of $2 \mathrm{mg} / \mathrm{l}$.

\section{References}

Anwar, A. A. (1999). Adjusted Factor $G a$ For Pipelines With Multiple Outlets and Outflow, Journal of Irrigation and Drainage Engineering, November/December 1999, 355359.

Bresler, E. (1977). Trickle-Drip Irrigation: Principles and Application to Soil-Water Management, Advances in Agronomy, 29, 343-393. http://dx.doi.org/ 10.1016/S00652113(08)60222-9

Colombo, A., and Oron, D. (2006). Plant water accessibility function: A design and management tool for trickleirrigation, Agricultural Water Management, 82(1-2), 4562. http://dx.doi.org/ 10.1016/j.agwat.2005.07.025

Gilary, E. (2008). Hydro Calc Irrigation Planning User Manual. Israel: NETAFIM Corporation.

Jackson, R. C., and Kay, M. G. (1987). Use of pulse irrigation for reducing clogging problems in trickle emitters, Journal of Agricultural Engineering Research, 37(3-4), 223-227.http://dx.doi.org/10.1016/S00218634(87)80019-7

Kale, R. V., Singh, R. P., and Mahar, P. S. (2008). Optimal Design of Pressurized Irrigation Subunit. Journal of Irrigation and Drainage Engineering, 134(2), 137-146. http://10.1061/ (ASCE)0733-9437(2008)134:2(137)

Keller, J., and Bliesner, R. D. (1990). Sprinkle And Trickle Irrigation, Van Nostrand Reinhold, New York, ISBN:0-442-24645-5.

Lesikar, B. J., Weynand, V. L., and Persyn, R. A. (2004). Evaluation of the Application Uniformity of Subsurface Drip Distribution Systems (pp. 73-83). In K. R. Mankin (Ed.). Wastewater Treatment $X, \quad$ Conference Proceedings (Number 701P0104). Sacramento, California, USA: ASAE Publication. Journal of Agricultural Science Vol. 4, No. 12; 2012133

Martí, P., Provenzano, G., Royuela, Á., and PalauSalvador, G. (2010). Integrated Emitter Local Loss Prediction Using Artificial Neural Networks. Journal of Irrigation and Drainage 
Engineering, 136(1), 11-22.http://10.1061/ (ASCE)IR.1943-4774.0000125

Molina-Martínez, J. M., and Ruiz-Canales, A. (2009). Pocket PC software to evaluate drip irrigation lateraldiameters with on-line emitters, Computers and Electronics in Agriculture, 69(1), 112-115.http://dx.doi.org/ 10.1016/j.compag.2009.06.006

Oron, G. (1982). Technical and economic considerations in the design of closed conduit irrigation systems: A case study. Agricultural Water Management, 5(1), 15-27. http://dx.doi. org/10.1016/0378-3774 (82)90035-X

Provenzano, G., Pumo, D., and Di Dio, P. (2005). Simplified Procedure to Evaluate Head Loss in Drip IrrigationLaterals. Journal of Irrigation and Drainage Engineering, 131(6), 525532.http://dx.doi.org/10.1061/(ASCE)07339437(2005)131:6(525)

Reynolds, C., Yitayew, M. andPetersenc, M. (1995). Low-head bubbler irrigation systems. Part I: Design, Agricultural Water Management, 29(1), 1-24. http://dx.doi.org/ 10.1016/0378-3774(95)01188-9

Sammis, T. W., Williams, S. and Wu, I. P. (1990). Development of a trickle irrigation scheduling model, Computers and Electronics in Agriculture, 5(3), 187-196. http://dx.doi.org/ 10.1016/0168-1699(90)90010-M

SCS. (1991). National Engineering Handbook, United States Department of Agriculture, Soil Conservation Service. Section 15: Irrigation, Chapter 7: Trickle Irrigation, 2nd Edition, 210VI, NEH 15-7.

Sepúlveda, E. S., Zazueta, F. S., Vergot, P., and Bucklin, R. A. (2005). Use of Handheld Computers for Hydraulic Calculations of Microirrigation Subunits (pp. 25-28). July 2005, Vila Real, Portugal.

Valiantzas, J. D. (2003). Closure to "Explicit Hydraulic Design of Microirrigation Submain
Units with Tapered Manifold and Laterals" by John D. Valiantzas. Journal of Irrigation and Drainage Engineering, 131(3), 299-300. http://10.1061/(ASCE)0733-9437(2005)131:3 (299.2)

Valiantzas, J. D. (2003). Explicit Hydraulic Design of Microirrigation Submain Units with Tapered Manifold and Lateral. Journal of Irrigation and Drainage Engineering, 129(4), 227-236.http://10.1061/(ASCE)0733-9437 (2003)129:4(227)

Valiantzas, J. D. (2003). Explicit Power Formula for the Carcy-Weisbach Pipe Flow Equation: Application in Optimal Pipeline Design. Journal of Irrigation and Drainage Engineering, 134(4), 454-461.http://dx.doi. org/10.1061/(ASCE)0733-9437(2008)134:4 (4 54)

Valiantzas, J. D., andDercas, N. (2005). Hydraulic Analysis of Multidiameter Center-Pivot Sprinkler Laterals, Journal of Irrigation and Drainage Engineering, 131(2), 137146.http://dx.doi.org/10.1061/(ASCE)07339437(2005)131:2(137)

Yazar, A., Sezen, S. M., andSesveren, S. (2002). LEPA and trickle irrigation of cotton in the Southeast Anatolia Project (GAP) area in Turkey. Agricultural Water Management, 54(3), 189-203.

Zapata, N., Playánb, E., Martínez-Cobb, A., Sáncheza, I., Facia, J. M., and Lecinac, S. (2007). From on-farmsolid-set sprinkler irrigation design to collective irrigation network design in windy areas, Agricultural Water Management, 87(2), 187-199. http://dx.doi.org/10.1016/j.agwat.2006.06.018.

\section{How to cite this article:}

Suryawanshi, O.P. 2018. Drip Irrigation Design and Management. Int.J.Curr.Microbiol.App.Sci. 7(04): 695-712. doi: https://doi.org/10.20546/ijcmas.2018.704.078 